\title{
Oral adenocarcinoma observed in Boa constrictor maintained in captivity
}

\section{Adenocarcinoma papilífero oral em jiboia (Boa constritor) mantida em cativeiro}

\author{
Washington Luiz Assunção Pereira ${ }^{1}$; Marcella Katheryne Marques Bernal ${ }^{2 *}$; \\ Antônio Messias Costa3; Aline Amaral Imbeloni ${ }^{4}$
}

\section{Highlights}

Boa kept in captivity developed neoplasm.

Histopathological analysis of tumor in the oral cavity of boa constrictor.

Adenocarcinoma as a diagnosis of malignant neoplasm in wild animals.

Further research for treatment and conservation of snakes.

\begin{abstract}
Information on neoplasms in animals has increased over time, and these studies have helped in the management of reptiles that present tumors. There are similar incidences of neoplasms between homeothermic and ectothermic animals. Furthermore, there are usually more than one type of tumor present. The treatment of wild animals afflicted with cancer usually happens late, contributing to their low life expectancy. Thus, the present work aimed to describe an infrequent case of oral tumor in Boa constrictor. The tumor was observed in an adult female animal, raised in an exhibition area of the Zoo and Botanical Park of the Emílio Goeldi Museum, located in Belém, State of Pará, Brazil. Macroscopically, the mass presented morphologically with an irregular, multilobulated surface, color that varied from white to grey, hemorrhagic areas and its extension was $3.9 \times 2.3 \mathrm{~cm}$. The neoplasm was surgically removed, and the histopathological evaluation revealed an adenocarcinoma, with a papillary-like development pattern and a moderate degree of differentiation. The animal died three months after diagnosis due to starvation. The necropsy showed that there was tumor recrudescence and no metastases. Given the impossibility of surgical removal with a greater margin of safety, and adjuvant therapies, this condition favoured the resurgence of the neoplasm. This compromised the animal's ability to feed and consequently lead to death. Malignant neoplasms in reptiles may have an unfavourable clinical evolution for the maintenance of life, requiring specific therapeutic care such as chemotherapy. Scientific contributions on tumors in these

1 Prof. Dr., Universidade Federal Rural da Amazônia, UFRA, Belém, PA, Brazil. E-mail: wkarton@terra.com.br

2 Student, Curso de Doutorado do Programa de Pós-Graduação em Saúde e Reprodução Animal na Amazônia,

Pesquisador Colaborador, Instituto Evandro Chagas, Seção de Hepatologia Animal, Belém, PA, Brazil. E-mail: mkbernalfh@gmail.com

3 Veterinarian, Museu Emílio Goeldi, Belém, PA, Brazil. E-mail: messias@museu-goeldi.br

4 Veterinarian, Belém, PA, Brazil. E-mail: alineimbeloni@yahoo.com.br

* Author for correspondence
\end{abstract}

Received: July 21, 2021 - Approved: Nov. 26, 2021 
animals are essential for the medical treatment of wild animals, and the conservation of wild species.

Key words: Boidae. Neoplasm. Oral cavity. Amazon.

\section{Resumo}

Estudos de neoplasias malignas e benignas em animais tem crescido ao longo do tempo, e os seus registros tem auxiliado no manejo de répteis que apresentam tumores. Descreve-se na literatura que há incidências semelhantes de neoplasmas entre animais homeotérmicos e ectotérmicos, e que estes geralmente apresentam mais de um tipo de tumoração. O tratamento de pacientes silvestres oncológicos geralmente acontece de forma tardia contribuindo para sua baixa sobrevida. Deste modo o presente trabalho objetivou descrever um caso infrequente de neoplasia oral em Boa constrictor. A casuística ocorreu num animal adulto, fêmea, criada em recinto de exposição do Parque Zoobotânico do Museu Emílio Goeldi, localizado em Belém, Estado do Pará, Brasil. Macroscopicamente a massa apresentou morfologicamente com superfície irregular, multilobulada, coloração que variou de branca a cinza, áreas hemorrágicas e sua extensão de $3,9 \times 2,3 \mathrm{~cm}$. A neoplasia foi removida cirurgicamente e a avaliação histopatológica revelou um adenocarcinoma, com padrão de desenvolvimento do tipo papiliforme e grau moderado de diferenciação. $\mathrm{O}$ animal foi a óbito três meses pós-diagnóstico por inanição. A necropsia demonstrou que havia recrudescência do neoplasma e ausência de metástases. Diante da impossibilidade da remoção cirúrgica com maior margem de segurança, e terapias adjuvantes, tal condição favoreceu o ressurgimento da neoplasia, comprometendo a alimentação e consequentemente levando ao óbito. Conclui-se que neoplasias malignas em répteis podem ter uma evolução clínica desfavorável a manutenção da sua vida necessitando de cuidados terapêuticos específicos como quimioterapia. As contribuições cientificas sobre processos neoplásicos nesses animais são fundamentais para a clínica médica de animais silvestres além de contribuir para a conservação de espécies silvestres.

Palavras-chave: Boidae. Neoplasia. Cavidade oral. Amazônia.

Neoplasms have been especially well-studied in domestic animals. However, a high incidence and variety of neoplastic diseases occur in ectothermic vertebrates, especially fish and amphibians. It is possible that the incidence of neoplasms in reptiles could be similar to that of other vertebrates. Furthermore, it could be that all major types of neoplasms found in endothermic vertebrates, including man, are seen in ectothermic vertebrates (Schlumberger \& Balduin, 1948). Wadsworth (1960) stated that there are no notable structural or morphological differences between snake tumors and those of neoplasms observed in mammals, birds and other reptiles.

In the National Zoological Park in Washington, USA, post-mortem examinations were carried out on 291 juvenile and adult snakes, from 1978 to 1997 (Catão-Dias \& Nichols, 2003). Of this total, 36 adult animals (24 females and 12 males) had neoplasms. Two snakes had neoplasms of two or three different types, but the other 34 snakes had only one type of tumor. Malignant neoplasms represented $79.5 \%$ and benign tumors $20.5 \%$. The malignant tumors can further be subdivided according to their origin. Malignant 
tumors of mesenchymal origin were $61.3 \%$ (19) of the tumors observed, while 11 (35.5\%) were of epithelial origin. In one case (3.2\%) the tumor derived from neuroectodermal tissue. The benign neoplasms were of epithelial origin. Lymphoid and hematopoietic tissue neoplasms were the most common 12 cases, followed by liver and biliary tract 7 cases and gastrointestinal 4 cases tumors.

At the Philadelphia Zoo, USA, a retrospective study of neoplasia in reptiles was carried out (Sykes \& Trupkiewicz, 2006). and it was observed that in 86 animals had neoplasms, with emphasis on snakes $(n=1835)$, neoplastic processes were identified in 53 animals (53/1835), and the liver was the organ with the highest occurrence of neoplasms, with $22 \%$ of neoplasms primaries (13/58); $10 \%(5 / 58)$ of the animals had multiple types of neoplasms, $9 \%(6 / 58)$ of the neoplasms had metastasis and $80 \%(42 / 58)$ of the tumors were diagnosed as malignant, skin neoplasms had an incidence of $24 \%$ ( $17 / 69)$ originated from biopsies.

In 2007 an adult female boa constrictor (Boa constrictor) from the exhibition area of the Zoo Botanic Park of the Emílio Goeldi Museum, located in Belém, State of Pará, Brazil, was examined due to significant weight loss. Upon inspection, in addition to emaciation, it was observed that the oral cavity remained semi-open with the presence of purulent exudate. On closer, physical examination presence of an irregular, solitary tumor was observed. It was embedded in the mucosa of the oropharyngeal region, The tumor had the appearance of a cauliflower and measured $3.9 \mathrm{~cm} \times 2.3 \mathrm{~cm}$; This structure had an elastic consistency and superficial hemorrhagic areas with a greyish-white color suggesting necrosis (Figure 1A).

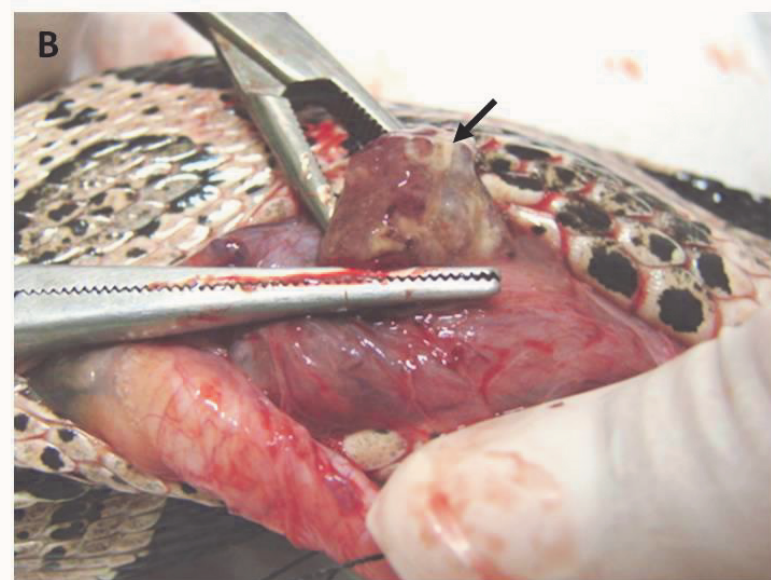

Figure 1A. Photomicrograph of oral papillary adenocarcinoma in Boa constrictor. A. Macroscopic aspects of a cauliflower-like neoplasm, measuring $3.9 \mathrm{~cm} \times 2.3 \mathrm{~cm}$, with a hemorrhagic surface and areas of necrosis (arrow). 1B. Procedure for removal of recurrent pharyngeal-esophageal neoplasm (arrow). Scale bar: $1.0 \mathrm{~cm}$. 
The neoplasm was surgically removed, but after three months, the animal died due to feeding difficulties. The specimen was necropsied, recording tumor recurrence in the oropharyngeal region below the surgical scar, with the process also present ventrally to the proximal region of the oesophagus (Figure 1B). Tumor fragments collected during surgery and post-mortem examination were fixed in a $10 \%$ neutral formalin solution and processed for histopathological analysis using a routine technique.

Microscopically, the tumor showed a papillary pattern (Figure 2a) with the formation of some tubules (Figure 2b). Moreover, the presence of vacuolated cells in apoptosis stages were observed, surrounded by an intensely vascularized myxoid stroma. The cells showed enlarged, pleomorphic nuclei, some of which were hyperchromatic (Figure 2c) and high mitotic index observed at 20/40x on objective with approximately 8 mitoses in 12 fields (Figure $2 \mathrm{~d}$ ). The tumor was infiltrative as could be observed in the myxoid stroma. Furthermore, coagulative necrosis and haemorrhages were seen. Clouds of bacteria and piocytes were also present. All these characteristics support the diagnosis of grade II papillary adenocarcinoma (moderately differentiated).

The occurrence of neoplasms in snakes has been described in several previous studies. For instance, Cassali, Amaral, Silva, Macri and Maciel (2004) recorded subcutaneous benign neoplasms in five Bothrops moojeni individuals kept in captivity for an average period of 11.4 years. These tumors were diagnosed as lipomatous tumors of the spindle cell lipoma subtype. Subcutaneously located spinal cell sarcoma has also been reported by Marcello, Maciel,
Ribeiro, Caliari and Cassali (2002) in jararaca (Bothrops leucurus), kept in captivity for seven years. Pereira and Viner (2008) reported the occurrence of oviduct adenocarcinoma in five captive snakes, with the presence of metastasis in all cases. Additionally, our present study and others involving malignant neoplasms describe the presence of hemorrhage, necrosis and inflammation. In the case reported, these aspects were also observed, with the development of these alterations being favored by the rapid tumor growth, exposure to bacteria and trauma.

Catão-Dias \& Nichols (2003) showed that digestive system neoplasms occur mainly in the liver, biliary tract and gastrointestinal branches. Among the neoplasms, gastric and intestinal adenocarcinomas are common in snakes. Intestinal adenocarcinomas are particularly reported in members of the Colubridae and tends to be located in the distal portion of the small intestine (Garner, 2004). Morphologically, adenocarcinomas (epithelial origin) have tubulopapillary patterns, are occasionally invasive and sometimes metastasize, especially to the liver (Garner, 2004). According to tumor histogenesis, demonstrating patterns compatible with reports in the literature.

Among the tumors associated with the digestive system of snakes, those of oral location are the least frequent (CatãoDias \& Nichols, 2003). The exception to this is species belonging to the Colubridae and Boidae (Garner, 2004). These families present higher prevalence for oral fibrosarcomas that are invasive and have moderate potential for metastasis. Furthermore, Chandra, Jacobson and Munn (2001) reported on a 19-year-old female Python molurus bivattatus with oral fibrosarcoma. 

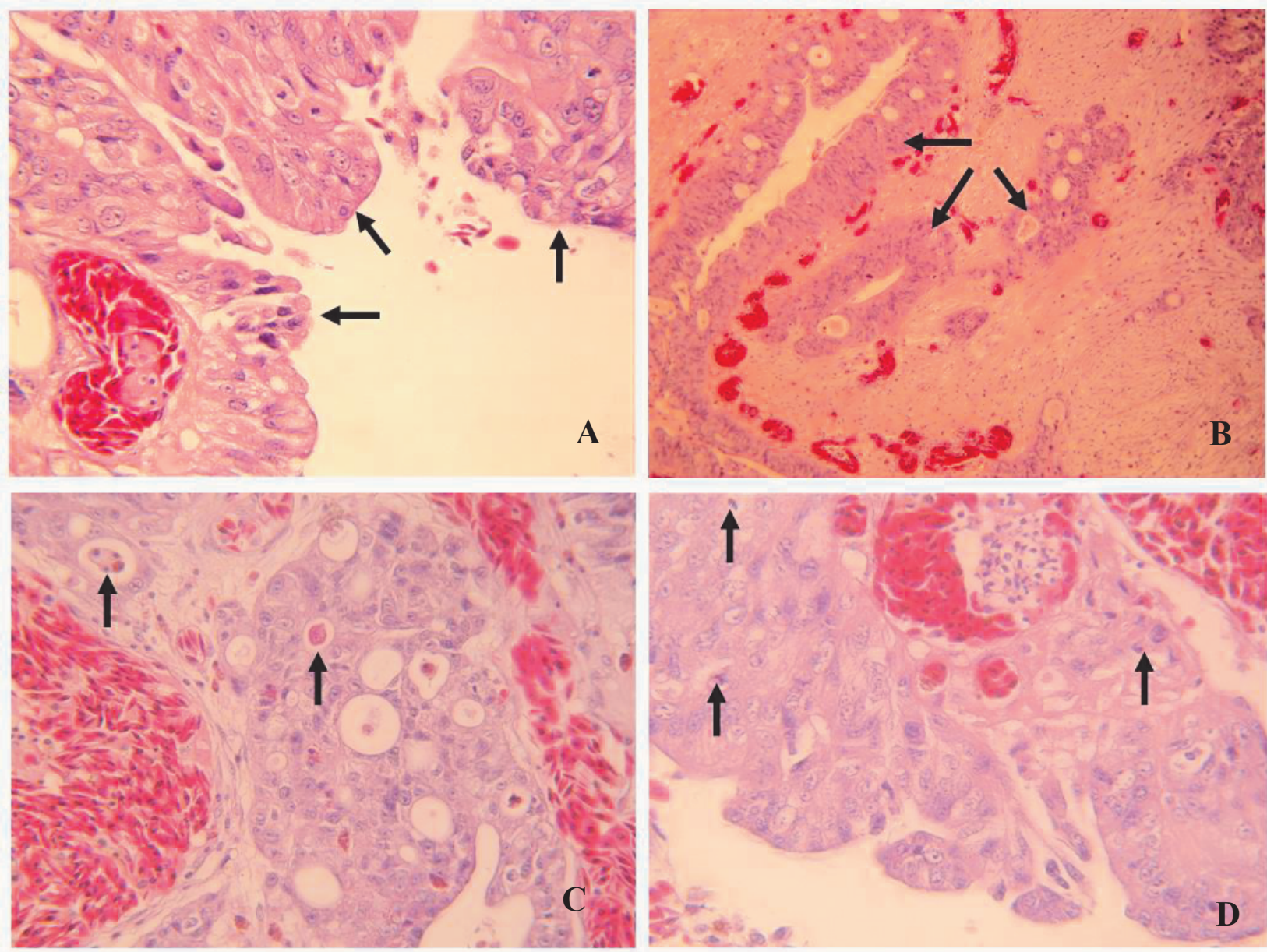

Figure 2A. Photomicrograph of oral adenocarcinoma in Boa constrictor showing multiple papillary formations (arrows), HE, 40x. 2B. Multiple tubular formations (arrows) surrounded by abundant myxoid stroma. HE, 10x. 2C. very vascularized stroma. Tumor tissue with cells presenting voluminous, pleomorphic nuclei, some hyperchromatic nuclei and many vacuolated cells in stages of apoptosis (arrow), HE, 40x. 2D. Magnification of mitosis figures (arrows), HE, 40x.

A study on humans by Conde, Leite, Calandro,LourençoandDias(2007)haveshown that squamous cell carcinoma represents approximately $90 \%$ of all oral malignancies, and the moderately differentiated tumor is the most frequent type. In ophidia, squamous cell carcinomas are occasionally common, being well differentiated, and having an invasive character destructive of the surrounding tissue (Garner, 2004). However, in the present study, although invasive behavior was observed, the tumor was diagnosed as papillary adenocarcinoma due to the histological results. This is a neoplasm that has been rarely referred to in the specialized literature.

It is concluded that the clinical signs associated with oral cavity tumors in snakes are easy to perceive, in a way that the animal may have a half-open mouth, and due to the 
exposure of the tumor, secondary infections may be present with purulent exudate. Death can occur due to the stress generated by the process and the progressive weakness of the animal, due to the impossibility of feeding. Neoplasms can occur in Boidae and records are essential in your clinic for the best management of the oncological animal.

\section{References}

Cassali, Amaral, Silva, Macri, \& Maciel, R. (2004). Communication. Cytological and histopathological aspects of lipomas in Bothrops moojeni. Arquivo Brasileiro de Medicina Veterinária e Zootecnia, 56(6), 799-801. doi: 10.1590/S0102-09352004 000600017

Catão-Dias, J. L., \& Nichols, D. K. (2003). Neoplasia in snakes at the National Zoological Park. Journal of Comparative Pathology, 120(1), 89-95. doi: 10.1053/ jсра.1998.0253

Chandra, A. M. S., Jacobson, E. R., \& Munn, R. J. (2001). Retroviral particles in neoplasms of Burmese pythons (Python molurus bivittatus). Veterinary Pathology, 38(1), 561-564. doi: 10.1354/vp.38-5-561

Conde, D. C., Leite, A. F. S. A., Calandro, T. L. L., Lourenço, S. Q. C., \& Dias, E. P. (2007). Epithelial precursor lesions and squamous cell carcinoma prevalence for a period of 10-years in the anatomic pathology service of the Antonio Pedro University Hospital, Fluminense Federal University. Applied Cancer Resarch, 27(1), 150-155. Recovered from https:// accamargo.phlnet.com.br/applied/ ACR20072 7p.156-60.pdf
Garner, M. M. (2004). Trends in reptilian neoplasia: a diagnostician's perspective. Proceeding of the Annual Meeting of the American College of Veterinary Pathologists (ACVP) \& Annual Meeting of the American Society of Clinical Pathology (ASVCP). Ithaca, New York, USA, 55, 39. Retrieved from hhttp://www. ivis.org

Marcello, H.B., Jr., Maciel, R., Ribeiro, C.A., Caliari, M. V., \& Cassali, G. D. (2002). Sarcoma fusocelular em jararaca - Bothrops leucurus. Arquivos Brasileiro de Medicina Veterinária e Zootecnia, 54(3), 1-4. doi: 10.1590/S0102-09352002000300018

Pereira, M. E., \& Viner, T. C. (2008). Oviduct adenocarcinoma in some species of captive snakes. Veterinary Pathology, 45(5), 693-697. doi: 10.1354/vp.45-5-693

Schlumberger, H. T., \& Balduin, L. (1948). Tumors of fishes, amphibians and reptiles. Cancer Research, 8(12), 657-754. Recovered from https://cancerres.aacrjournals.org/ content/8/12/657.long

Sykes, J. M., \& Trupkiewicz, J. G. (2006). Reptile neoplasia at the Philadelphia zoological garden, 1901-2002. Journal of Zoo and Wildlife Medicine, 37(1), 11-19. doi: 10.1638/04-112.1

Wadsworth, J. R. (1960). Tumors and tumorlike lesion of snakes. Journal of the American Veterinary Medical Association, 137(1), 419-420. Recovered from https:// avmajournals.avma.org/action/doSearch? AllField=Tumors+and+tumor-like+lesion+ of + snakes\&SeriesKey=\&submit $=+$ Go 